\title{
The HOXB13 p.Gly84Glu mutation is not associated with the risk of breast cancer
}

\author{
Mohammad R. Akbari • Wojciech Kluźniak • Rachelle Rodin • Song Li • \\ Dominika Wokołorczyk • Robert Royer • Aniruddh Kashyap · Janusz Menkiszak • \\ Jan Lubinski · Steven A. Narod · Cezary Cybulski
}

Received: 5 October 2012/ Accepted: 10 October 2012/Published online: 26 October 2012

(C) The Author(s) 2012. This article is published with open access at Springerlink.com

\begin{abstract}
Recently, the HOXB13 gene has been shown to be a susceptibility gene for prostate cancer. HOXB13 is overexpressed in breast cancer tissues and HOXB13 expression in combination with low expression of IL17BR is predictive for a tamoxifen response in ER-positive breast cancers. Based on observations, we hypothesized that the HOXB13 p.Gly84Glu mutation might be associated with breast cancer risk. We genotyped this mutation in the germline DNA of 4,037 women with breast cancer (including 1,082 familial cases) and in 2,762 controls from Canada and Poland. Seven heterozygous carriers of the HOXB13 p.Gly84Glu mutation were found in the cases $(0.17 \%)$ compared to four carriers among the controls $(0.14 \%$; $\mathrm{OR}=1.2,95 \% \mathrm{CI}=0.34-4.1, p=1.0)$. Only one of the seven carriers had a family history of breast cancer. This study does not support the hypothesis that women who carry the HOXB13 Gly84Glu mutation are at increased risk of breast cancer.
\end{abstract}

M. R. Akbari · R. Rodin - S. Li · R. Royer - S. A. Narod Women's College Research Institute, Women's College Hospital, University of Toronto, Toronto, Canada

\section{R. Akbari · S. A. Narod}

Dalla Lana School of Public Health, Faculty of Medicine, University of Toronto, Toronto, Canada

W. Kluźniak · D. Wokołorczyk · A. Kashyap · J. Lubinski · C. Cybulski (凹) International Hereditary Cancer Center, Department of Genetics and Pathology, Pomeranian Medical University, ul. Połabska 4, 70-115 Szczecin, Poland

e-mail: cezarycy@sci.pum.edu.pl

J. Menkiszak

Department of Surgical Gynecology and Gynecological Oncology of Adults and Adolescents, Pomeranian Medical University, Szczecin, Poland
Keywords Breast cancer $\cdot$ HOXB13 - p.Gly84Glu

$\begin{array}{ll}\text { Abbreviations } \\ \text { BRCA1 } & \text { Breast cancer susceptibility gene 1 } \\ \text { BRCA2 } & \text { Breast cancer susceptibility gene 2 } \\ \text { BRIP1 } & \text { BRCA1 interacting protein 1 } \\ \text { CHEK2 } & \text { Checkpoint kinase 2 } \\ \text { CI } & \text { Confidence interval } \\ \text { DNA } & \text { Deoxyribonucleic acid } \\ \text { ER } & \text { Estrogen receptor } \\ \text { Glu } & \text { Glutamine } \\ \text { Gly } & \text { Glycine } \\ \text { HOXB13 } & \text { Homeobox B13 } \\ \text { OR } & \text { Odds ratio } \\ \text { PALB2 } & \text { Partner and localizer of BRCA2 }\end{array}$

\section{Introduction}

The risk of breast cancer varies between women, and genetic susceptibility plays an important role in the etiology of the disease. Two major breast cancer susceptibility genes, BRCA1 [1] and BRCA2 [2], were identified in the 1990s. Hereditary breast cancer cases are estimated to account for $10 \%$ of all breast cancers and BRCA1 and BRCA2 genes are responsible for only $15-20 \%$ of the inherited breast cancers [3]. More recently, other breast cancer genes such as BRIP1 [4], CHEK2 [5], and PALB2 [6] have been discovered, but mutations in those genes are rare and account for only a small percentage of families.

Recently, the HOXB13 p.Gly84Glu mutation was reported to be associated with the increased risk of prostate cancer [7]. This mutation increases the risk of prostate cancer by 5- to 10-fold [8, 9]. HOXB13 belongs to the HOX family of transcription factor genes, each containing a homeodomain. 
These genes are located in four clusters throughout the human genome (HOXA, B, C, and D) and are involved in embryonic development [10], but they are also expressed in different organs in the adult, including breast tissue [11]. HOXB13 is overexpressed in breast cancers compared to the normal breast $[12,13]$, and high expression of HOXB13 in combination with low expression of IL17BR has been reported to be predictive of a poor response to tamoxifen therapy in ER-positive breast cancer patients [14, 15]. Based on these observations, we hypothesized that the HOXB13 p.Gly84Glu mutation might be associated with breast cancer risk.

\section{Methods}

We genotyped the HOXB13 p.Gly84Glu mutation in germline DNA of 4,037 breast cancer cases and in 2,762 controls. Subjects included 1,804 breast cancer cases and 925 controls from Canada and 2,233 breast cancer cases and 1,837 controls from Poland. The Canadian cases were all white women and were selected from patients who received genetic counseling at the cancer genetics clinics in Toronto between 1998 and 2011. The mean age at diagnosis of these patients was 52.2 years (range 18-89). The Polish cases include prospectively ascertained series of invasive breast cancer diagnosed throughout Poland with early onset breast cancer (age range 20-50; mean 44.4). They were ascertained from 18 different hospitals between 1996 and 2003. Of the total 4,037 breast cancer cases,
1,085 patients had at least one affected individual among their first-degree relatives (familial cases). Canadian controls were obtained from the Healthwatch (HW) screening program at the Women's College hospital. These are healthy women with no prior history of cancer who had attended a multimodal screening clinic for well women at the Women's College Hospital in Toronto. The Polish controls consisted of 1,837 unselected cancer-free women (age range 24-84 years; mean age 54.0 years), selected at random from the computerized patient lists of five large family practices located in the region of Szczecin in 2003. Cases and controls were restricted to women of European origin as previous studies in prostate cancer $[7,8]$ found the HOXB13 p.Gly84Glu mutation only among men of European decent. The study was approved by the ethics review board of the participating institutions.

Genotyping of the HOXB13 p.Gly84Glu mutation among cases and controls was performed using the TaqMan assay on ABI 7500 fast and 7900 real-time systems (Applied Biosystems Co., Foster City, CA, USA). All mutation carriers identified by genotyping were confirmed by direct sequencing using the BigDye Terminator Cycle Sequencing kit on an ABI 3500XL DNA Analyzer (Applied Biosystems Co., Foster City, CA, USA). We compared the frequency of the HOXB13p.Gly84Glu mutation between cases and controls using Fisher's exact test and calculated odds ratios (OR) and their $95 \%$ confidence intervals (CI) based on $2 \times 2$ table analysis of the cases and controls. All statistical tests were two-sided and $p$ values $<0.05$ were considered statistically significant.

Table 1 Clinical characteristics of 11 individuals carrying germline HOXB13 G84E mutation

\begin{tabular}{|c|c|c|c|c|c|c|c|c|}
\hline No. & Origin & Subjects & $\begin{array}{l}\text { Age at } \\
\text { diagnosis, y }\end{array}$ & $\begin{array}{l}\text { Estrogen } \\
\text { receptor }\end{array}$ & $\begin{array}{l}\text { Progesterone } \\
\text { receptor }\end{array}$ & HER2 & Grade & Family history $^{\mathrm{b}}$ \\
\hline 1 & Canada & Case & 78 & + & + & $?$ & Ca ductal G3 & None \\
\hline 2 & Canada & Case & 74 & + & + & - & Ca ductal G2 & $\begin{array}{l}\text { Father (PrCa), maternal aunt } \\
\quad(\mathrm{BrCa})\end{array}$ \\
\hline 3 & Poland & Case & $50^{\mathrm{a}}$ & + & ++ & - & Ca ductal Gx & None \\
\hline 4 & Poland & Case & 50 & - & - & - & Ca ductal G3 & None \\
\hline 5 & Poland & Case & 47 & + & - & $?$ & $\begin{array}{l}\text { Ca ductal G1, } \\
\text { G2 }\end{array}$ & $\begin{array}{l}\text { Mother (BrCa), paternal aunt } \\
\text { (BrCa) }\end{array}$ \\
\hline 6 & Poland & Case & 47 & - & - & + & $\begin{array}{l}\text { Ca ductal G1, } \\
\text { G2 }\end{array}$ & $\begin{array}{l}\text { Father }(\mathrm{PrCa}) \text {, paternal grandfather } \\
\text { (PrCa) }\end{array}$ \\
\hline 7 & Poland & Case & 41 & - & - & + & Ca medullar & None \\
\hline 8 & Canada & Control & 57 & NA & NA & NA & NA & None \\
\hline 9 & Poland & Control & 50 & NA & NA & NA & NA & None \\
\hline 10 & Poland & Control & 70 & NA & NA & NA & NA & None \\
\hline 11 & Poland & Control & 40 & NA & NA & NA & NA & None \\
\hline
\end{tabular}

${ }^{a}$ Poland cases were selected for their age and they were all under 50 years of age

b Family history of breast cancer ( $\mathrm{BrCa}$ ) and prostate cancer $(\mathrm{PrCa})$ among the first-and second-degree relatives of the probands

$(+)$ or $(++)$ positive; (-) negative; ? unknown; NA not available; HER2 Human Epidermal Growth Factor Receptor 2 


\section{Results}

The detailed clinical characteristics of the cases and controls carrying the HOXB13 p.Gly84Glu mutation are shown in Table 1. Seven heterozygous carriers of the HOXB13 p.Gly84Glu mutation were identified among the 4,037 cases $(0.17 \%)$ and four carriers were seen among the 2,762 controls $(0.14 \%)(\mathrm{OR}=1.2,95 \% \mathrm{CI}=0.3-4.1, p=1.0)$. Only one of the seven carrier cases had a first-degree relative with breast cancer, and after limiting the comparison to familial cases, still no association was seen between HOXB13 p.Gly84Glu and breast cancer (OR = 0.6, $95 \%$ $\mathrm{CI}=0.1-5.7, p=0.9)$.

\section{Discussion}

The association of HOXB13 p.Gly84Glu and increased risk of prostate cancer has been confirmed in several large scale case-control studies [8-10]. In a follow-up study, Alanee et al. reported that [16] this mutation was also associated with an increased risk of familial breast cancer $(\mathrm{OR}=5.7$, $95 \% \mathrm{CI}: 1.0-40.7, p=0.02)$. The authors found that, among study subjects with familial breast cancer who were negative for BRCA1/2 mutations, the carrier frequency of p.Gly84Glu $(0.7 \%)$ was seven times higher than in their control group $(0.1 \%)$. This study was based on 877 familial cases, out of which 6 had a mutation. In our much larger series of familial and non-familial cases, we observed similar frequencies between all cases and controls ( 0.17 and $0.14 \%$ respectively) and even lower frequency $(0.09 \%)$ was seen among familial cases and we did not confirm the association between HOXB13 p.Gly84Glu and increased risk of breast cancer. However, the HOXB13 p.Gly48Glu allele is very rare (approximately one in a thousand) and we are unable to rule out a small effect.

The relatively high expression level of HOXB13 in breast tumor cells compared to normal breast cells [12-15] suggests a possible oncogenic role for HOXB13, although activating mutations have not been reported. However, the prostate cancer studies are unable to distinguish between an oncogenic or tumor suppressor effect for HOXB13 [17], given that it is not known if the p.Gly84Glu mutation leads to loss or gain of function and truncating variants which are suggestive of a tumor suppressor effect have not been seen [7].

Acknowledgments We acknowledge Dr. Kathleen A. Cooney from the University of Michigan Medical School for providing us their TaqMan assay design for genotyping HOXB13 p.Gly84Glu mutation. We also acknowledge Mr. Jacek Gronwald, Mr. Tomasz Huzarski, and Mr. Tomasz Byrski for their help in recruiting Polish patients.

Conflict of interest None
Open Access This article is distributed under the terms of the Creative Commons Attribution Noncommercial License which permits any noncommercial use, distribution, and reproduction in any medium, provided the original author(s) and the source are credited.

\section{References}

1. Miki Y, Swensen J, Shattuck-Eidens D et al (1994) A strong candidate for the breast and ovarian cancer susceptibility gene BRCA1. Science 266:66-71

2. Wooster R, Bignell G, Lancaster J et al (1995) Identification of the breast cancer susceptibility gene BRCA2. Nature 378:789-792

3. Narod SA, Foulkes WD (2004) BRCA1 and BRCA2: 1994 and beyond. Nat Rev Cancer 9:665-676

4. Seal S, Thompson D, Renwick A, Elliott A, Kelly P, Barfoot R et al (2006) Truncating mutations in the Fanconi anemia J gene BRIP1 are low-penetrance breast cancer susceptibility alleles. Nat Genet 38(11):1239-1241

5. Meijers-Heijboer H, van den Ouweland A, Klijn J, Wasielewski M, de Snoo A, Oldenburg R et al (2002) Low-penetrance susceptibility to breast cancer due to CHEK2(*)1100delC in noncarriers of BRCA1 or BRCA2 mutations. Nat Genet 31(1):55-59

6. Rahman N, Seal S, Thompson D, Kelly P, Renwick A, Elliott A et al (2007) PALB2, which encodes a BRCA2-interacting protein, is a breast cancer susceptibility gene. Nat Genet 39(2):165-167

7. Ewing CM, Ray AM, Lange EM, Zuhlke KA, Robbins CM, Tembe WD et al (2012) Germline mutations in HOXB13 and prostate-cancer risk. N Engl J Med 366(2):141-149

8. Akbari MR, Trachtenberg J, Lee J, Tam S, Bristow R, Loblaw A et al (2012) Association between germline HOXB13 G84E mutation and risk of prostate cancer. J Natl Cancer Inst 104(16): $1260-1262$

9. Breyer JP, Avritt TG, McReynolds KM, Dupont WD, Smith JR (2012) Confirmation of the HOXB13 G84E germline mutation in familial prostate cancer. Cancer Epidemiol Biomarkers Prev 21(8):1348-1353

10. Graham A (1994) Developmental patterning: the Hox code out on a limb. Curr Biol 4:1135-1137

11. Nunes FD, de Almeida FC, Tucci R, de Sousa SC (2003) Homeobox genes: a molecular link between development and cancer. Pesqui Odontol Bras 17(1):94-98

12. Cantile M, Pettinato G, Procino A, Feliciello I, Cindolo L, Cillo C (2003) In vivo expression of the whole HOX gene network in human breast cancer. Eur J Cancer 39(2):257-264

13. Ma XJ, Wang Z, Ryan PD, Isakoff SJ, Barmettler A, Fuller A et al (2004) A two-gene expression ratio predicts clinical outcome in breast cancer patients treated with tamoxifen. Cancer Cell 5(6):607-616

14. Ma XJ, Hilsenbeck SG, Wang W, Ding L, Sgroi DC, Bender RA et al (2006) The HOXB13:IL17BR expression index is a prognostic factor in early-stage breast cancer. J Clin Oncol 24(28): 4611-4619

15. Jansen MP, Sieuwerts AM, Look MP, Ritstier K, Meijer-van Gelder ME, van Staveren IL et al (2007) HOXB13-to-IL17BR expression ratio is related with tumor aggressiveness and response to tamoxifen of recurrent breast cancer: a retrospective study. J Clin Oncol 25(6):662-668

16. Alanee S, Couch F, Offit K (2012) Association of a HOXB13 variant with breast cancer. N Engl J Med 367(5):480-481

17. Jung C, Kim RS, Zhang HJ, Lee SJ, Jeng MH (2004) HOXB13 induces growth suppression of prostate cancer cells as a repressor of hormone-activated androgen receptor signaling. Cancer Res 64:9185-9192 